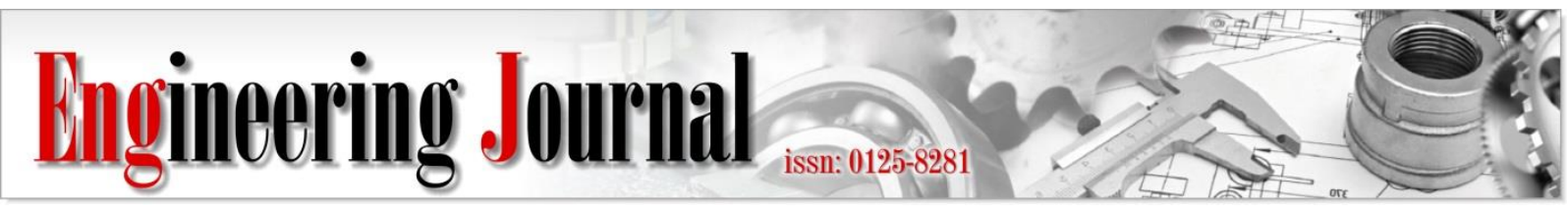

Article

\title{
Seismic Analysis of RC Frames with Brick Infill Panel Strengthened by Steel Cage and Expanded Metal
}

\author{
Phaiboon Panyakapo \\ Department of Civil Engineering and Town Development, School of Engineering, Sripatum University, \\ Bangkok, 10900, Thailand \\ E-mail: phaiboon.pa@spu.ac.th
}

\begin{abstract}
The seismic analysis of reinforced concrete infilled frame strengthened by using steel cage and expanded metal was investigated. The strengthening technique of steel cage consisted of steel angle, batten and expanded metal sheet was employed. The brick infill panel was strengthened with ferrocement and expanded metal. The flexible base foundation was considered by modelling the pile foundation with the lateral and the vertical spring stiffness. Eight types of frames: four existing frames and four retrofit frames were analyzed by nonlinear static analysis and nonlinear time history analysis with 20 ground motion records. It was found that the initial stiffness and the strength of the retrofit frames were significantly higher than those of the existing frames. The observed seismic damage of the retrofit frames was decreased to the specified limit. The initial stiffness of the frames with flexible foundation was lower than that of the fixed base resulting to the larger displacement and the higher seismic damage of the structures.
\end{abstract}

Keywords: Seismic, strengthening, steel cage, nonlinear static analysis, nonlinear time history analysis.

ENGINEERING JOURNAL Volume 25 Issue 4

Received 11 May 2020

Accepted 2 April 2021

Published 30 April 2021

Online at https:/ / engj.org/

DOI:10.4186/ej.2021.25.4.29 


\section{Introduction}

Existing reinforced concrete buildings were damaged under earthquake load due to insufficient flexural and shear reinforcements of longitudinal and transverse bars in the columns. The 2014 Mae Lao earthquake revealed that many buildings were severely damaged due to the deficiency of column reinforcement (Lukkunaprasit et al., 2015) [1]. Therefore, seismic retrofit is required to prevent collapse of these buildings. Among the strengthening techniques of column, the steel cage is a well-known method which consists of steel angles at the corners of column and steel batten at a specified spacing along the column height. This technique is widely used for retrofitting after earthquakes (Murty et al., 2005; Wasti \& Ozcebe, 2006) [2, 3] due to its effective in cost and improvement. Many researchers have studied the strengthening technique of steel cage. Nagaprasad et al. (2009) [4] proposed the design method of seismic strengthening of columns with steel cage which was verified by an experimental study. The strengthened columns showed the improvement on the strength, stiffness and ductility. However, the specimens are limited to two strengthened columns with different types of batten. The wider end batten enhanced the moment capacity and the lateral strength. This finding is consistent with the analytical results of Salman \& AlSherrawi (2018) [5] who studied the axial load and bending moment interaction diagram of reinforced concrete columns with various sizes of steel batten. In addition, the reduction of spacing of steel batten also enhanced the bending moment capacity of the strengthened column. An experiment on the reinforced concrete columns with steel cage was investigated under axial force and bending moment by Roca et al. (2011) [6] Two types of capital were used to connect the steel cage with the beam-column joint: chemical anchors and penetrated steel bars. It was found that the specimens with steel bars provided greater strength and ductility than the chemical anchors. However, there was no explanation for the design method of strengthening for the steel cage. A comparison of load carrying capacity of $\mathrm{RC}$ column strengthened with steel cage was conducted by Campione (2012) [7]. The analytical expressions for load capacity were compared with the experimental results. It was found that the reduction of the batten spacing and column width ratio caused an increase of load capacity. However, the study did not consider for the lateral load capacity of strengthened columns. Campione et al. (2015) [8] proposed an analytical model to predict the flexural response of reinforced concrete beam-column joint strengthened with steel cage. The load-deflection curves obtained by the developed model showed good agreement with the experimental results. The model is useful for investigating the seismic performance of structures retrofitted with steel cage. An application of Glass Fiber Reinforced Polymers (GFRP) with steel cage technique for seismic shear strengthening of RC beam-column joint was proposed by Esmaeeli et al. (2017) [9]. The technique is useful to retrofit the beam-column joint by anchoring the GFRP sheet to the steel cage without any penetration to the concrete. The shear strength, stiffness, ductility and energy dissipation capacity of the retrofit frame were enhanced.

For the case of structures rested on soft soil sites, it is known that the effects of flexible foundation cause a reduction of structural stiffness resulting to the lengthening of the natural period of structures. The influence of soil-structure interaction on the seismic behavior of the structures has been studied by several researchers. A study on the seismic performance of multi-story building with flexible base was investigated by $\mathrm{Lu}$ et al. (2016) [10]. It was found that the design lateral force distributions specified by the current codes are suitable for the long period structures with flexible base. For the short period structures, the trapezoidal lateral force is suggested when consider for flexible base. However, the study is limited for the existing structures without strengthening. The effects of stratified soil on the fundamental period of flexible base structures were investigated by Medina et al. (2019) [11]. The models of pile group were considered for soil structure interaction effect for different slenderness of structures. It was concluded that the flexible base period of the slender structure was decreased with the increase of the shear wave velocity through the soil profiles. Choiniere et al. (2019) [12] investigated the influence of soil structure interaction on the seismic behavior of building with shear wall. The foundation was modeled to support by the vertical and lateral springs including damping. The results revealed that the soil structure model provided the reasonable results for nonlinear time history analysis, and the fixed base model underestimated the seismic demand. It is suggested that the effect of soil structure should be considered for the normal soil type. For the case of fixed base model, the column force in the first story should be amplified. Recently, Ramadan et al. (2020) [13] studied the seismic behavior of continuous bridges considering soil structure interaction for different soil profile. It was demonstrated that the soil structure provided more effect on the operational limit state than the collapse limit state. However, none of the previous study investigates the soil structure interaction effect on the retrofitted structure.

In this study, a three-story standard school building was selected as the prototype reinforced concrete frame to strengthen with steel cage and expanded metal. The beams and columns were strengthened with the technique of steel cage, which was composed of steel angles, battens and expanded metal. The brick infill panel was strengthened with expanded metal sheet. The foundation was modeled as flexible base taking account of the soil structure interaction effect. The retrofit frames were analyzed by nonlinear static analysis and nonlinear time history analysis. 


\section{Analytical Models of Strengthened Frame and Infill Panel}

\subsection{Strengthened Bare Frame}

The model of reinforced concrete bare frame strengthened with steel cage technique is shown in Fig. 1(a). The purpose of strengthening is to enhance the lateral resistance of the frame by strengthening the beam and the column members. The steel angles are installed at the corners of column, and the longitudinal alignment of steel angle is tied by steel battens at a specified spacing. The expanded metal sheets are placed in the area enclosed by the steel cage. Detail arrangement of steel cage is shown in Fig. 1(b).

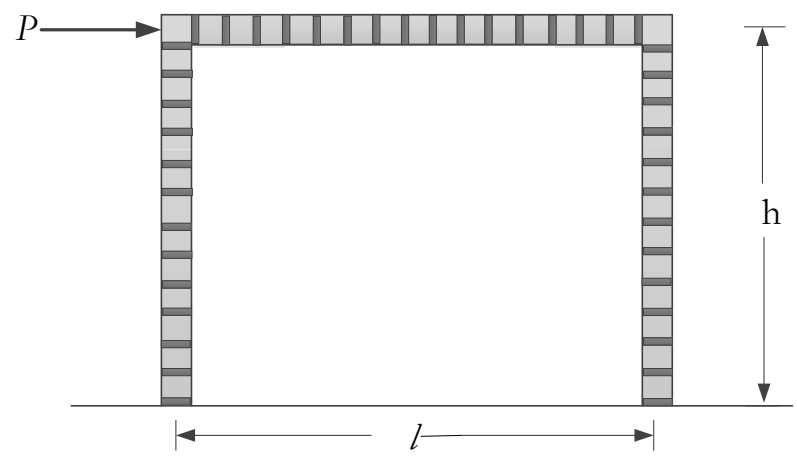

(a) Strengthening frame

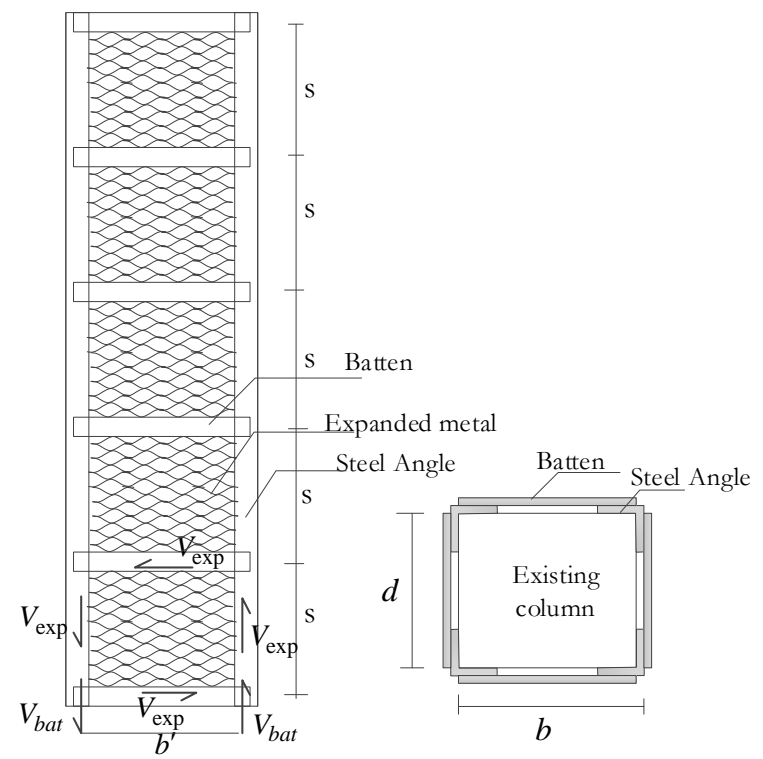

(b) Details of steel cage

Fig. 1. Strengthening of bare frame by steel cage and expanded metal.

The moment capacity of the strengthened column $\left(M_{s t}\right)$ is a combination of the existing moment capacity of column and the steel cage, and it can be calculated as follows:

$$
M_{s t}=M_{c}+M_{s c}
$$

where $M_{s t}$ is the moment capacity of the strengthened column; $M_{c}, M_{s c}$ are the moment capacity of the existing column and steel cage, respectively.

The existing moment capacity of a reinforced concrete column subjected to low axial load $(N)$ may be calculated according to Tumialan et al. (2001) [14].

$$
M_{c}=A_{s t} f_{y} g d+0.5 N d\left(1-\frac{N}{b d f_{c}^{\prime}}\right)
$$

where $A_{s t}$ is the total longitudinal reinforcing steel area; $g$ is the ratio of the distance between the longitudinal reinforcement in tension and compression to the column thickness; $f_{c}^{\prime}, f_{y}$ are the compressive strength of concrete and the yield strength of reinforcement; $b, d$ are the width and the depth of column.

The moment capacity of steel cage $\left(M_{s c}\right)$ is equal to the moment capacity of four steel angles $\left(M_{\text {ang }}\right)$ placed at the corner of column which can be calculated by using the transformed section modulus of four steel angles $(Z)$ multiplied by their yield strength $\left(f_{y}\right)$ as follows:

$$
M_{s c}=f_{y} Z
$$

The moment capacity of steel angle $\left(M_{\text {ang }}\right)$ is balanced by the sum of the resisting moments of batten and expanded metal along the column height which is dependent on the number of battens $\left(N^{\prime}\right)$ and the center to center spacing of steel angle $(b)$, as shown in Eq. (4). Since the moment capacity of the steel cage $\left(M_{s c}\right)$ is governed by the yielding resistant of the steel angle, an overstrength factor of 1.25 was applied to the moment capacity of steel angle to ensure yielding of steel angle prior to battens and expanded metal sheets.

$$
1.25 M_{\text {ang }}=2 V_{b a t} b^{\prime} N^{\prime}+2 V_{\exp } b^{\prime}\left(N^{\prime}-1\right)
$$

The design shear force of batten $\left(V_{b a t}\right)$ can be calculated by dividing the moment capacity of steel batten with the center to center spacing of steel angle (b). The design shear force of expanded metal $\left(V_{\text {exp }}\right)$ is derived from the moment equilibrium of Eq. (4).

The design shear force of the strengthened column $\left(V_{s c}\right)$ for a bare frame can be determined by dividing the sum of the end moment of the strengthened column by the column height.

$$
V_{s c}=\frac{\left(M_{p j}+M_{s t}\right)}{b}
$$

where $M_{p j}$ is the least of the plastic moment of column, beam and joint connection.

Since the bare frame consists of two columns, therefore, the shear force of the bare frame $\left(V_{b f}\right)$ is twice the shear force of the strengthened column $\left(V_{s c}\right)$.

$$
V_{b f}=2 V_{s c}
$$




\subsection{Strengthened Brick Infill Panel}

To improve the lateral strength of brick infill panel, the infill panel is strengthened by using ferrocement technique with expanded metal mesh technique (Leeanansaksiri et al., 2018 and Longthong et al., 2020) $[15,16]$. For the case of infilled frame with the full height brick panel, the analysis of the lateral strength of the infill panel presented by Longthong et al. (2020) [16] is adopted in this study.

For the case of the partial infill panel which is the infilled frame with a wide widow opening at the upper part of infill panel as shown in Fig. 2(a). The infilled frame is composed of a partial brick panel with the height of $h_{1}$ and the window opening with the height of $h_{o}$. The strut force of the infill panel is governed by the diagonal compression rather than the corner compression and sliding shear failure mechanism. To determine the strength envelop of infill panel (Fig. 2(b)), the lateral yield strength $V_{\mathrm{y}}$ and the maximum strength $V_{\mathrm{m}}$ of infill panel can be calculated as follows:

$$
\begin{aligned}
& V_{y}=F_{t} \cos \theta=w t f_{t} \cos \theta \\
& V_{m}=F_{m} \cos \theta=w / f_{a} \cos \theta
\end{aligned}
$$

where $f_{t}$ and $f_{a}$ are the tensile strength and the allowable compressive strength of the brick prism strengthened with ferrocement, which may be calculated as $f_{t}=0.25 \phi \sqrt{f_{m}^{\prime}}, \quad f_{a}=0.6 \phi f_{m}^{\prime}, \quad \phi=0.65 ; \quad f_{m}^{\prime} \quad$ is the compressive strength of brick prism; $t$ is the thickness of brick panel. The compressive strength of composite materials of brick prism is dependent on the quantity of the specific surface of expanded metal. The relationships between the compressive strength, $f_{m}^{\prime}$ and the specific surface of reinforcement, $S_{r}$ of ferrocement obtained from the prism test can be found in the study of $\mathrm{R}$. Amornpunyapat et al. (2021) [17].

The strut width of the brick panel can be derived from the contact length of the stress distribution of the frame and infill interface proposed by Saneinejad \& Hobbs (1995) [18] as follows:

$$
\begin{aligned}
w & =\alpha_{c} b_{1} \frac{l_{m}}{\sqrt{b_{1}^{2}+l_{m}^{2}}}=\alpha_{c} h_{1} \cos \theta \\
\alpha_{c} & =\frac{1}{b} \sqrt{\frac{2 M_{p j}+2 \beta_{c} M_{p c}}{\sigma_{c} t}} \\
\sigma_{c} & =\frac{f_{m}^{\prime}}{\sqrt{1+3 \mu^{2} r^{4}}}
\end{aligned}
$$

where $\mu$ is the friction coefficient between the frame and the brick panel, $r=h / l ; \beta_{c}$ is the multiplying factor of column $\left(\beta_{c}=0.2\right) ; M_{p c}$ is the plastic moment of column; $M_{p j}$ is the least moment among the moment capacities of beam, column and joint connection.

$$
\begin{aligned}
\Delta_{y} & =\varepsilon_{y} L_{d} / \cos \theta \\
\Delta_{m} & =\varepsilon_{m} L_{d} / \cos \theta \\
L_{d} & =\sqrt{\left(1-\alpha_{c}\right)^{2} h_{1}^{2}+l_{m}^{2}}
\end{aligned}
$$

where $\varepsilon_{y}, \varepsilon_{m}$ are the strains at the yield and the maximum of the strengthened masonry prism.

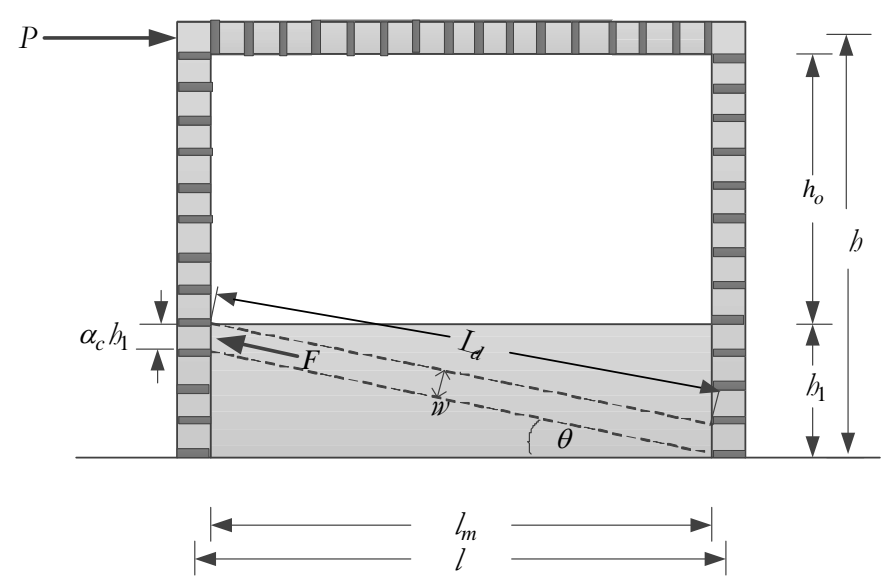

(a) Strut force

Lateral Force $(V)$

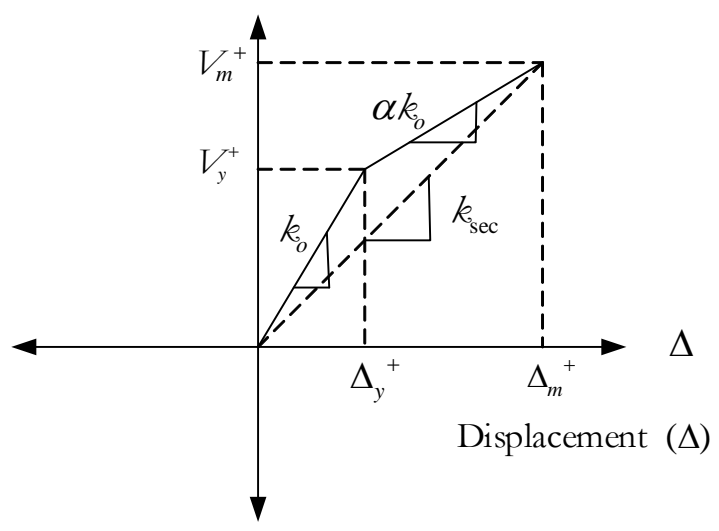

(b) Strength envelope

Fig. 2. Diagonal strut for brick infill panel and strength envelop.

The parameter $k_{0}$ is the initial stiffness, $\alpha k_{0}$ is the post yield stiffness, $\alpha$ is the bilinear factor, $k_{\text {sec }}$ is the secant stiffness. These can be determined from the following equations:

$$
\begin{aligned}
& k_{o}=\frac{V_{y}}{\Delta_{y}} \\
& \alpha k_{o}=\frac{V_{m}-V_{y}}{\Delta_{m}-\Delta_{y}} \\
& \alpha=\frac{V_{m}-V_{y}}{\Delta_{m}-\Delta_{y}} \cdot \frac{\Delta_{y}}{V_{y}} \\
& k_{\mathrm{sec}}=\frac{V_{m}}{\Delta_{m}}
\end{aligned}
$$




\section{Strengthening Method of the School Building}

\subsection{Selected Building}

A three-story building according to the standard school of the National Primary Education Commission No.2/28 was selected. The layout of the building is $10.00 \times 56.00$ meters with the height of 11.20 meters. The front of the building is a bare frame (Fig. 3(a)). The back of building is infilled frame with partial brick panels, and solid brick at both ends of building for the ground floor (Fig. 3(b)). The typical floor is cast in-situ concrete slab supported by the reinforced concrete frame. The cylindrical concrete strength and the reinforcement yield strength were $21 \mathrm{Mpa}$ and $240 \mathrm{Mpa}$, respectively. The details of columns and beams are shown in Table 1.

Table 1. Reinforcing details of the frame.

\begin{tabular}{lccc}
\hline Member & $\begin{array}{c}\text { Dimension } \\
(\mathbf{m m})\end{array}$ & $\begin{array}{c}\text { Long. } \\
(\mathbf{m m})\end{array}$ & $\begin{array}{c}\text { Tran. } \\
\text { (mm) }\end{array}$ \\
\hline $\mathrm{C} 1$ & $350 \times 450$ & $8 \mathrm{RB} 19$ & $2 \mathrm{RB} 6 @ 200$ \\
\hline $\mathrm{C} 2$ & $300 \times 300$ & $8 \mathrm{RB} 15$ & $\mathrm{RB} 6 @ 200$ \\
\hline $\mathrm{B} 2$ & $200 \times 400$ & 5RB15 & RB6@200 \\
\hline
\end{tabular}

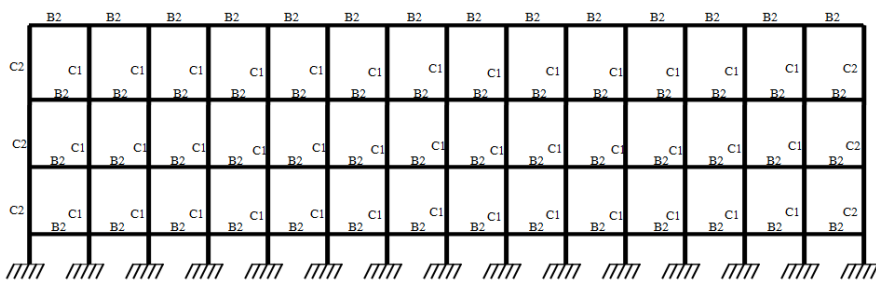

(a) Front-view Bare frame (BF)

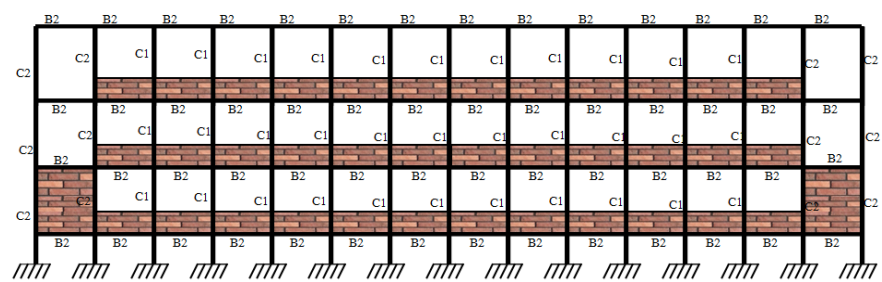

(b) Back-view Infilled frame (IF)

Fig. 3. Existing building structural model.

\subsection{Strengthening Method}

The detail arrangement of the strengthening steel cage technique conducted by P. Panyakapo(2017)[19] was employed in this study. The steel cage was composed of $65 \times 65 \times 5 \mathrm{~mm}$ steel angle assembled at the corners of column. The end of steel angle at the footing was welded to the steel plate which was attached to the footing with high strength bolts to transfer the bending moment capacity of steel angle. The steel angles were welded with $100 \times 322 \times 6 \mathrm{~mm}$ steel batten at a spacing of $367 \mathrm{~mm}$. along the column height. To enhance the shear strength of steel cage, the expanded metal sheet was placed and welded with the surrounding area enclosed by steel angle and batten. To improve the lateral resistance of brick panel, the expanded metal sheet was laminated with both sides of wall and attached with $6 \mathrm{~mm}$ bolts at a spacing of $300 \mathrm{~mm}$. Finally, the wall panel was plastered with cement mortar according to the ferrocement technique. Details of strengthening technique are presented in Fig. 4.

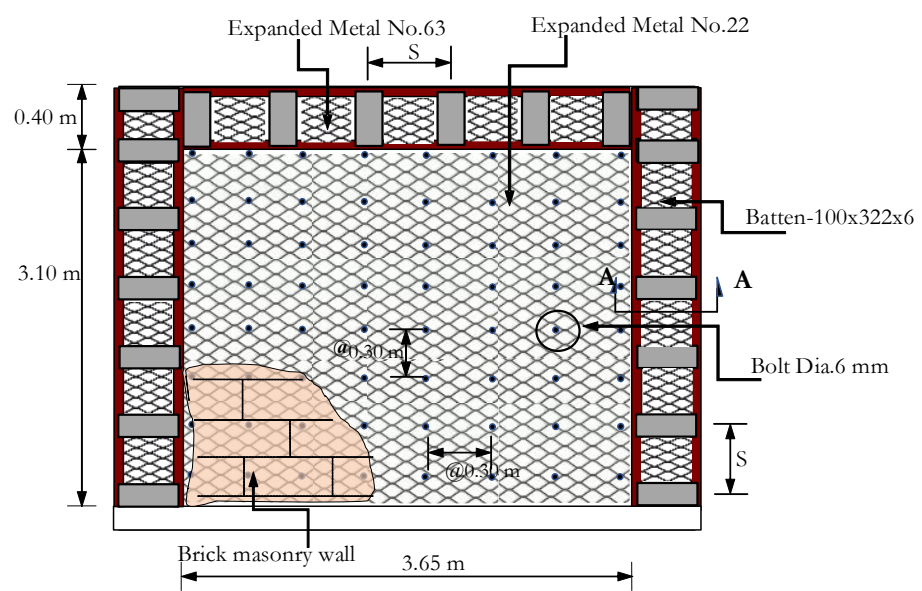

a) Infilled frame

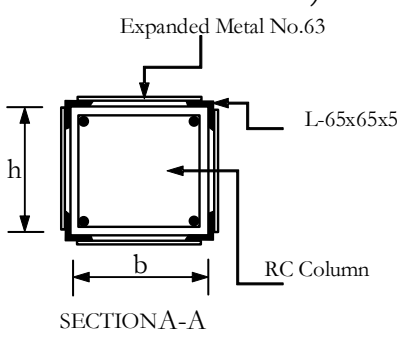

b) column section

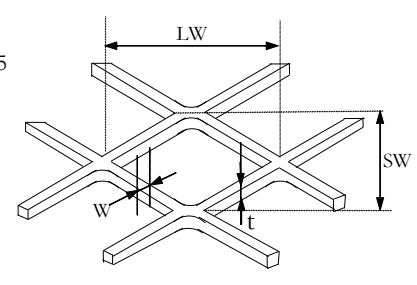

c) expanded metal mesh
Fig. 4. Strengthening of infilled frame with steel cage and expanded metal.

The expanded steel mesh was the standard type diamond shape mesh. The physical properties of expanded metal sheet (Table 2) conformed to JIS G3351 [20] Standard with the yield strength and the ultimate strength of $340 \mathrm{Mpa}$ and $400 \mathrm{Mpa}$, respectively.

Table 2. Properties of Expanded Metal.

\begin{tabular}{cccccc}
\hline Type & $\begin{array}{c}\text { SW } \\
\mathbf{m m}\end{array}$ & $\begin{array}{c}\mathbf{L W} \\
\mathbf{m m}\end{array}$ & $\begin{array}{c}\text { Thickness } \\
(\mathbf{t}) \mathbf{~} \mathbf{m m}\end{array}$ & $\begin{array}{l}\text { Width } \\
(\mathbf{w}) \mathbf{m m}\end{array}$ & $\begin{array}{c}\text { Weight } \\
\mathbf{k g} / \mathbf{m}^{\mathbf{2}}\end{array}$ \\
\hline No.22 & 8.6 & 20.0 & 0.6 & 0.6 & 0.69 \\
\hline XS.63 & 34 & 76.2 & 4.5 & 4.5 & 9.68 \\
\hline
\end{tabular}

To implement this strengthening technique, for the front view frame (Fig. 5a), the columns at the first floor and the beams at the second floor were strengthened with steel cage (SC). In addition, the brick infill panels with strengthened ferrocement (WR) were added at both ends of the frame to enhance the stiffness and the strength of the frame. For the back view frame (Fig. 5(b)), the columns for the $1^{\text {st }}$ and the $2^{\text {nd }}$ floors and the beams at the $2^{\text {nd }}$ and the $3^{\text {rd }}$ floors were strengthened with steel cage (SC). The strengthened brick infill panels (WR) were added at both ends of the frame similar to the front view frame. 


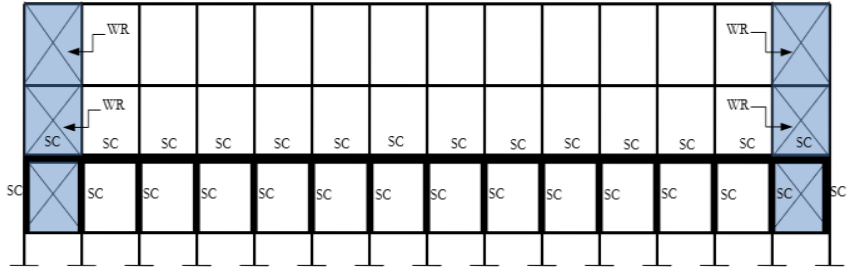

(a) Front-view strengthened frame

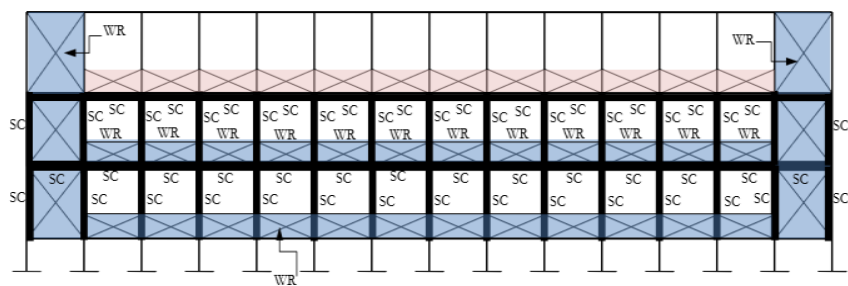

(b) Back-view strengthened frame

Fig. 5. Strengthened frame model: (a) Front-view strengthened frame, (b) Back-view strengthened frame.

\section{Hysteresis Model of Strengthened Frame and Foundation Model}

\subsection{Calibration of Hysteresis Model with Experimental Result}

The proposed analytical model of the strengthened frame and infill panel presented in the previous section was implemented in the modelling of the infilled frame for the school building. To validate the hysteresis behavior of the strengthened frame, the strengthened bare frame (BF-S) and the strengthened infilled frame (IF-S) were modeled as a couple of simple frame with single bay and one story height by employing the nonlinear computer program RUAUMOKO (Carr, 2006) [21], as shown in Figs. 6a-6b. Both frames are exactly the same as the frames that were tested in the laboratory conducted by Panyakapo (2017) [19]. The hysteresis behavior of beam and column was modeled by using Modified Takeda (Otani 1974) [22]. The equivalent strut was modeled for the infill panel based on SINA degrading tri-linear (Saiidi and Sozen 1979) [23]. The strength parameters of the strengthened bare frame are presented in Table 3. The hysteresis model parameters of the strengthened infill panel are shown in Table 4.

Table 3. Strength parameters of bare frame.

\begin{tabular}{lc}
\hline Strength parameters & Strengthened bare frame \\
\hline $\mathrm{M}_{\mathrm{c}}(\mathrm{kN}-\mathrm{m})$ & 101.37 \\
\hline $\mathrm{M}_{\mathrm{sc}}(\mathrm{kN}-\mathrm{m})$ & 140.24 \\
\hline $\mathrm{M}_{\mathrm{st}}(\mathrm{kN}-\mathrm{m})$ & 241.61 \\
\hline $\mathrm{M}_{\mathrm{pj}}(\mathrm{kN}-\mathrm{m})$ & 24.93 \\
\hline $\mathrm{V}_{\mathrm{sc}}(\mathrm{kN})$ & 83.29 \\
\hline $\mathrm{V}_{\mathrm{bf}}(\mathrm{kN})$ & 166.58 \\
\hline
\end{tabular}

Table 4. Hysteresis parameters of infill panel.

\begin{tabular}{cc}
\hline $\begin{array}{c}\text { Hysteresis } \\
\text { parameters }\end{array}$ & Strengthened infill panel \\
\hline $\mathrm{V}_{\mathrm{y}}(\mathrm{kN})$ & 301.21 \\
\hline$\Delta_{\mathrm{y}}(\mathrm{mm})$ & 4.65 \\
\hline $\mathrm{V}_{\mathrm{m}}(\mathrm{kN})$ & 339.66 \\
\hline$\Delta_{\mathrm{m}}(\mathrm{mm})$ & 14.52 \\
\hline
\end{tabular}

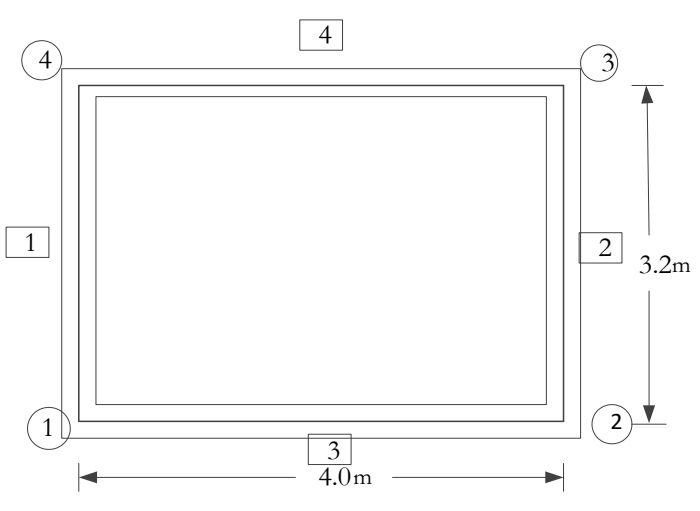

(a) strengthened bare frame (BF-S)

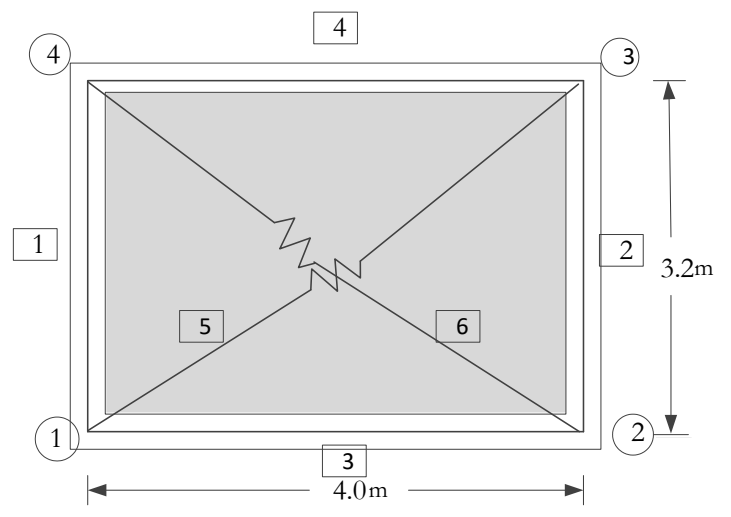

(b) strengthened infilled frame (IF-S)

Fig. 6. Modelling of bare frame and infilled frame.

The Cyclic Pushover Analysis presented by P. Panyakapo (2014) [24] was performed for the strengthened bare frame (BF-S) and the strengthened infilled frame (IF-S). The laboratory type protocol was applied to the frames in the same way as that employed in the previous study [19]. The hysteresis behavior results of the analysis model and the experiment are compared for BF-S and IF-S in Figs. 7(a) and 7(b), respectively. The shear strength of the strengthened bare frame BF-S based on Eq. (6) is $166.58 \mathrm{kN}$ that is $6.53 \%$ difference when it is compared with the test result of $156.37 \mathrm{kN}$. In addition, the shear strength of the strengthened infilled frame IF-S based on Eq. (6) and Eq. (8) is $506.24 \mathrm{kN}$ that is $2.06 \%$ difference when it is compared with the test result of $496 \mathrm{kN}$. The results showed a good agreement between the proposed analytical models and the test results for both frames which indicated that the proposed models could be implemented. 


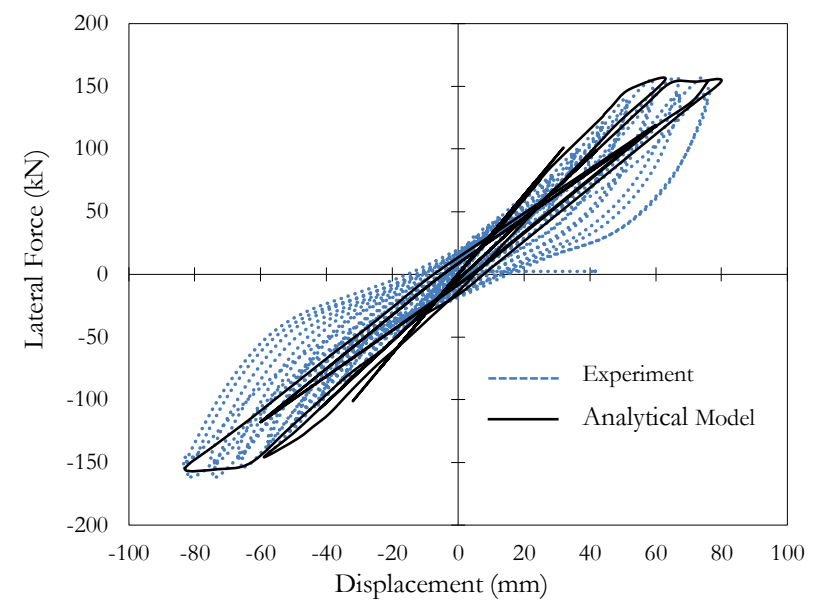

(a) BF-S

Fig. 7. Comparison of analytical model and experiment

\subsection{Foundation Model}

The footing layout of this building was isolated footing with pile foundation. The pile is prestressed concrete with $0.26 \times 0.26 \mathrm{~m}$ I-shape cross section and $12.0 \mathrm{~m}$ length. The building was assumed to locate at Mae Lao district, Chiang Rai province in the northern part of Thailand where the pile was embedded in the soil profile as shown in Fig. 8. The selection of I-shape pile was to evaluate the more severity case of section property when compared to the rectangular section. Since the stiffness of the I-shape pile is lower than the solid rectangular pile, therefore, the larger the lateral displacement of the I-shape pile foundation.

The pile foundation was modelled to support by a series of lateral spring along the pile depth and a spring at the pile tip as shown in Fig. 9. The lateral spring was placed at a spacing of $1.0 \mathrm{~m}$. The stiffness of the lateral spring $\left(\mathrm{k}_{\mathrm{s}}\right)$ was determined by using the computer program LPILE [25]. In this analysis, the lateral loaddeflection curves ( $\mathrm{p}-\mathrm{y}$ curves) of each soil layer was computed based on the soil model for stiff clay proposed by Reese et al. (1977) and Lymon et al. (2001) [26, 27], as shown in Fig. 10(a). The stiffness of each lateral spring $\left(\mathrm{k}_{\mathrm{s}}\right)$ was obtained by computing the secant slope of the $\mathrm{p}$ $y$ curve. For the spring of the pile tip, the stiffness of the pile tip $\left(\mathrm{k}_{\mathrm{a}}\right)$ was determined by using the computer program APILE [28]. In this analysis, the loadsettlement curve of the pile was computed based on the API-RP 2A method [29], as shown in Fig. 10(b). The stiffness of spring $\left(\mathrm{k}_{\mathrm{a}}\right)$ was obtained by computing the secant slope of the load-settlement curve.

It should be remarked that the p-y curves in soil modelling are modelled using the secant stiffness to prevent numerical instability under the nonlinear time history analysis. This method is commonly employed in the modelling of soil to represent the overall stiffness of soil. The secant stiffness takes account of degradation of stiffness; therefore, the effective stiffness is lower than the initial stiffness.

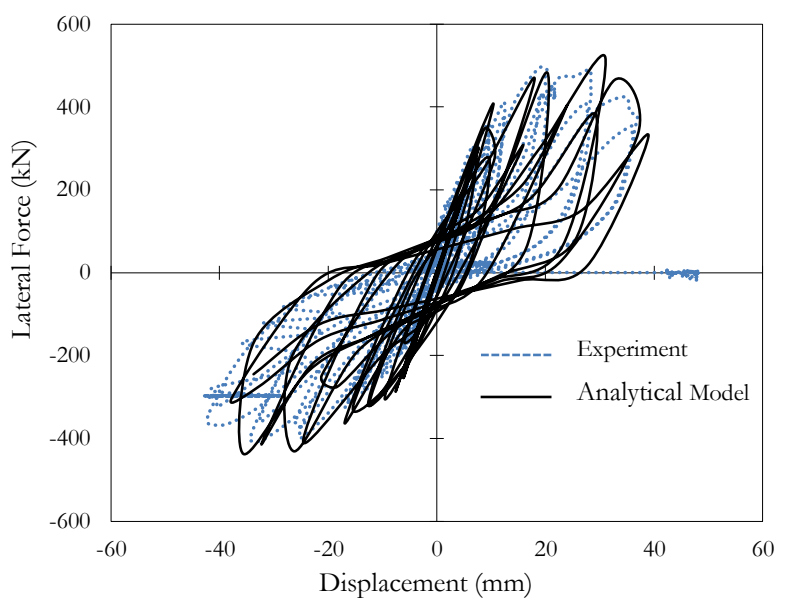

(b) IF-S

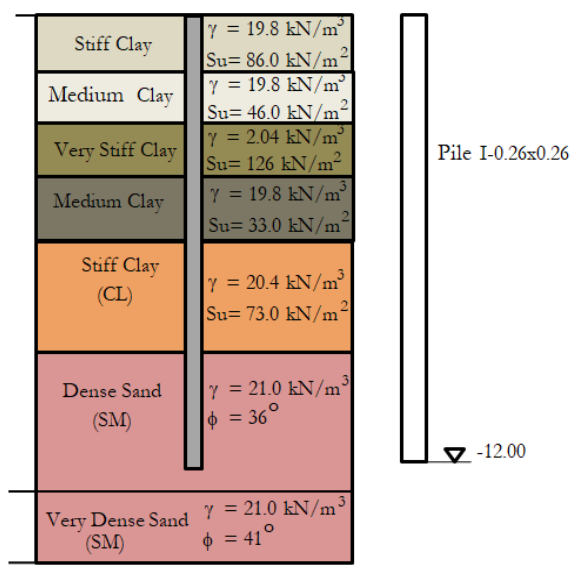

Fig. 8. Soil profile and engineering properties.

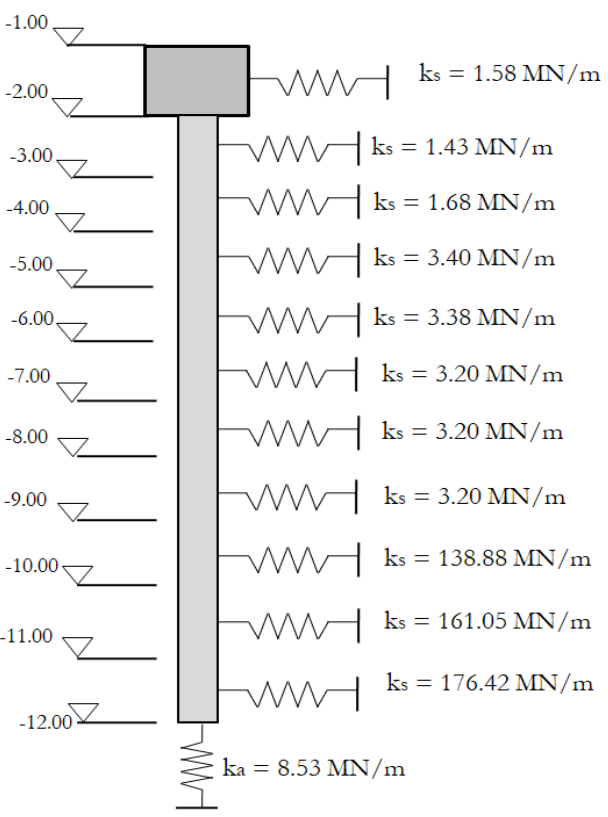

Fig. 9. Pile spring model for flexible foundation. 


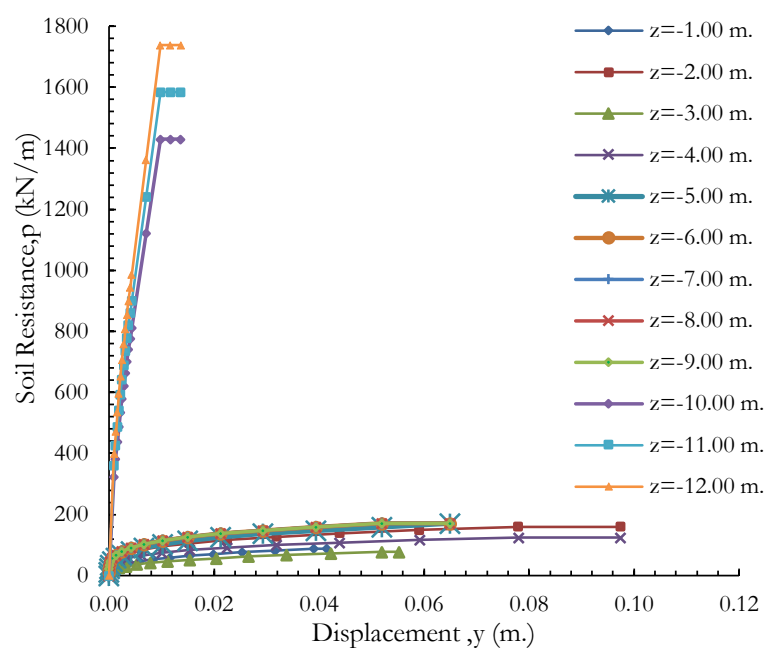

(a) P-y curves for each soil layer

Fig. 10. Load deflection curves of pile.

\section{Analysis of Strengthened Frame}

In this analysis, the existing frames and the strengthened frames are separated into 8 types according to the characteristic of the frame and the foundation models, as follows:

- Type 1 and Type 3 are the existing bare frame with fixed foundation and flexible foundation, respectively.

- Type 2 and Type 4 are the strengthening bare frame with fixed foundation and flexible foundation, respectively.

- Type 5 and Type 7 are the existing brick infilled frame with fixed foundation and flexible foundation, respectively.

- Type 6 and Type 8 are the strengthening brick infilled frame with fixed foundation and flexible foundation, respectively.

The above descriptions for the structural model types 1-8 are presented in Table 5.

Table 5. Structural models for analysis.

\begin{tabular}{llc}
\hline Type & Structure & Foundation \\
\hline 1. BF-F & Existing Bare Frame & Fixed \\
\hline 2. BF-F-ST & Strengthening Bare Frame & Fixed \\
\hline 3. BF-SP & Existing Bare Frame & Flexible \\
\hline 4. BF-SP-ST & Strengthening Bare Frame & Flexible \\
\hline 5. IF-F & Existing Infilled Frame & Fixed \\
\hline 6. IF-F-ST & Strengthening Infilled Frame & Fixed \\
\hline 7. IF-SP & Existing Infilled Frame & Flexible \\
\hline 8. IF-SP-ST & Strengthening Infilled Frame & Flexible \\
\hline
\end{tabular}

\subsection{Nonlinear Static Analysis}

The nonlinear static analysis was performed for the above structures to determine the base shear force and roof displacement relationship. The distribution of lateral load was evaluated based on the seismic weight of each frame. The weight of the front view bare frame was

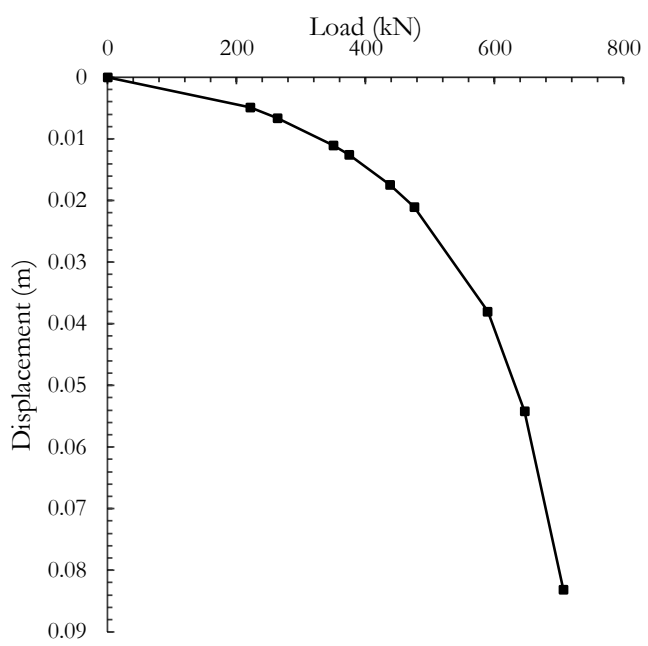

(b) Load-Displacement curve for pile tip

mainly due to the mass of the floor slab and beams. The weight of the back view infilled frame was greater than the bare frame due to the addition of the infill panel, and hence, the higher lateral load. The lateral applied force was gradually increased until the roof displacement reached the target displacement which was computed according to ASCE 41-06 [30]. The target displacement $\left(\delta_{t}\right)$ was calculated as follows:

$$
\delta_{\mathrm{t}}=C_{0} C_{1} C_{2} S_{a} T_{\mathrm{e}}^{2} g / 4 \pi^{2}
$$

where $C_{0}, C_{1}, C_{2}$ are the modification factors related to spectral displacement, expected maximum inelastic displacement, and the effect of hysteresis shape, respectively; $S_{a}$ is the response spectrum acceleration corresponding to Mae Lao district, Chiang Rai province according to DPT (2009) [31], $g=9.81 \mathrm{~m} / \mathrm{s}^{2}$; and $T_{\mathrm{e}}$ is effective fundamental period (sec).

To investigate the peak strength level, the analysis was carried out to the extended target displacement at least $150 \%$ of $\delta_{t}$ according to the recommendation of ASCE 41-06 [30]. The target displacements of the bare frames and the infilled frames were calculated as shown in Table 6-7. The extended target displacements for the bare frames are larger than those of infilled frames because the effect of infill panel caused an increase of the overall structural stiffness and hence a reduction of the displacement. Therefore, the expected displacements of the infill frames are lower than those of the bare frames.

Table 6. Target displacement of bare frames. 
Table 7. Target displacement of infilled frames.

\begin{tabular}{|c|c|c|c|}
\hline \multirow[t]{2}{*}{ Structures } & \multirow{2}{*}{$\begin{array}{l}\text { Period } \\
T_{e}, \text { sec }\end{array}$} & \multicolumn{2}{|c|}{ Target Displacement } \\
\hline & & $\delta_{\mathrm{t}}, \mathrm{mm}$. & $1.5 \delta_{\mathrm{t}}, \mathrm{mm}$ \\
\hline Type 5 (IF-F) & 0.57 & 55.10 & 82.65 \\
\hline Type 6 (IF-F-ST) & 0.36 & 32.18 & 48.27 \\
\hline Type 7 (IF-SP) & 0.70 & 65.21 & 97.82 \\
\hline Type 8 (IF-SP-ST) & 0.48 & 48.47 & 72.71 \\
\hline
\end{tabular}

The results of nonlinear static analysis for the structural types 1-4 and the structural types 5-8 are shown in Figs. 11(a) and 11(b), respectively. In addition, the stiffness, strength and the displacement capacity of bare frames (Types 1-4) and the infilled frame (Types 5-8) are calculated based on the pushover curves as presented in Tables 8-9. The displacement capacity was defined as the maximum displacement that the system could sustain the load to the extended $\delta_{\text {t. }}$. It may be less than the extended $\delta_{t}$ when the analysis was terminated due to failure of some structural members.

For the case of bare frames, the stiffness and strength of the retrofit frame with fixed base (Type 2) are 3.47 and 2.94 times of the existing bare frame (Type 1). This is due to the contribution of the strengthened brick infill frame at both ends of the frame and the strengthened bare frame at the intermediate columns. The effect of flexible foundation of the existing frame (Type 3) reduced the stiffness and strength of the existing bare frame (Type 1) by $40 \%$ and $10 \%$. In addition, the effect of flexible foundation on the strengthened frame (Type 4) could reduce the stiffness and strength of the strengthened bare frame (Type 2) by $45 \%$ and $22 \%$. The effect of flexible foundation caused a lengthening of the effective period of structures, and hence a reduction of the stiffness and strength. The displacement capacity of the strengthened frame (Type 2) is lower than the existing frame (Type 1) because the addition of strengthened infill panel caused an increase of stiffness which is consistent with the experimental results presented in the previous section. The effect of flexible

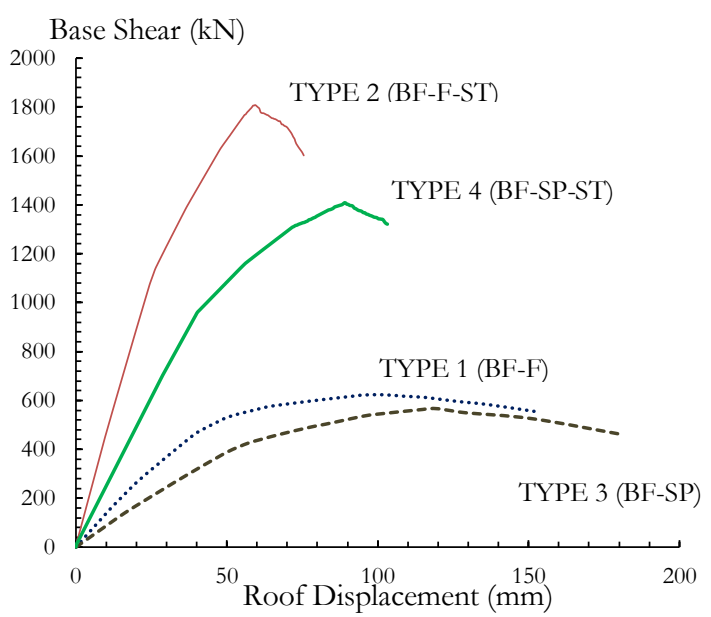

(a) Frame Types 1-4 foundation enhanced the displacement capacity for both the existing frame and the retrofit frame (Type 3, 4).

For the case of infilled frames, the stiffness and strength of the retrofit frame with fixed base (Type 6) are 2.32 and 1.57 times of the existing infilled frame (Type 5). The effect of flexible foundation of the existing infilled frame (Type 7) reduced the stiffness and strength of the existing infilled frame (Type 5) by $27 \%$ and $21 \%$. Similarly, the effect of flexible foundation on the strengthened infill frame (Type 8) could reduce the stiffness and strength of the strengthened infill frame (Type 6) by $27 \%$ and $15 \%$. For the displacement capacity, the behavior of infilled frame was similar to that of the bare frame. The displacement capacity of the strengthened frame (Type 6) is lower than the existing frame (Type 5) due to the increase of stiffness of the infill panel and the frame. The effect of flexible foundation enhanced the displacement capacity for both the existing frame and the retrofit frame (Type 7, 8).

Table 8. Stiffness, strength and displacement capacity of bare frames (Type 1-4).

\begin{tabular}{lccc}
\hline Structures & $\begin{array}{l}\text { Stiffness } \\
(\mathbf{k N} / \mathbf{m m})\end{array}$ & $\begin{array}{c}\text { Strength } \\
(\mathbf{k N})\end{array}$ & $\begin{array}{c}\text { Displacement } \\
\text { capacity }(\mathbf{m m})\end{array}$ \\
\hline 1. BF-F & 12.9 & 614 & 151.79 \\
\hline 2. BF-F-ST & 44.78 & 1,806 & 75.49 \\
\hline 3. BF-SP & 7.68 & 554 & 181.56 \\
\hline 4. BF-SP-ST & 24.51 & 1,403 & 103.21 \\
\hline
\end{tabular}

Table 9. Stiffness, strength and displacement capacity of infilled frames (Type 5-8).

\begin{tabular}{lccc}
\hline Structures & $\begin{array}{c}\text { Stiffness } \\
(\mathbf{k N} / \mathbf{m m})\end{array}$ & $\begin{array}{c}\text { Strength } \\
\mathbf{( k N )}\end{array}$ & $\begin{array}{c}\text { Displacement } \\
\text { capacity }(\mathbf{m m})\end{array}$ \\
\hline 5. IF-FIX & 34.23 & 1,493 & 71.36 \\
\hline 6. IF-FIX-ST & 79.45 & 2,343 & 45.01 \\
\hline 7. IF-SP & 25.14 & 1,179 & 85.98 \\
\hline 8. IF-SP-ST & 57.95 & 1,994 & 61.01 \\
\hline
\end{tabular}

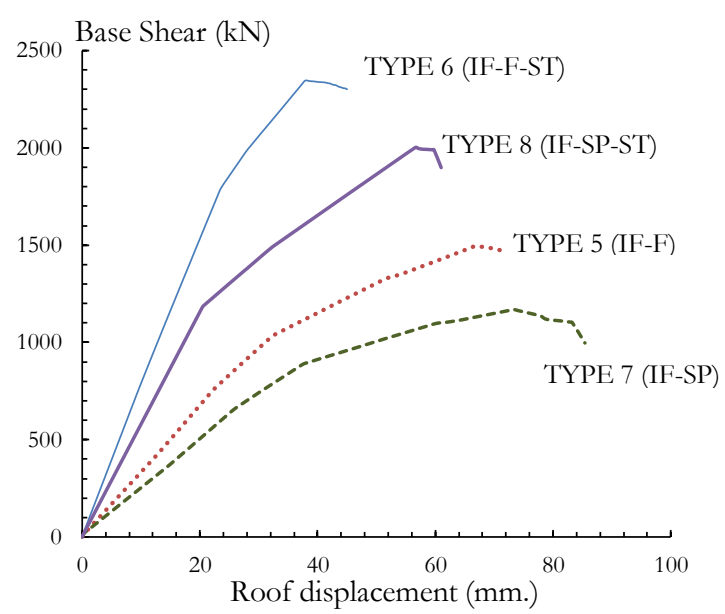

(b) Frame Types 5-8

Fig. 11. Pushover Curves. 


\subsection{Nonlinear Time History Analysis}

The nonlinear time history analysis was conducted for the frames type 1-8 to investigate the inter-story drift level and the plastic hinge formation at the beam and column members by using RUAUMOKO (Carr, 2006) [21]. The 20 ground motions were selected and scaled to the Maximum Considered Earthquake (MCE) response spectrum for Mae Lao district, Chiang Rai province according to DPT (2009) [31], as shown in Table 10.

Table 10. Ground motions and scale factors.

\begin{tabular}{clcc}
\hline No & \multicolumn{1}{c}{ Earthquake records } & $\begin{array}{c}\text { PGA } \\
\mathbf{( g )}\end{array}$ & $\begin{array}{c}\text { Scale } \\
\text { factor }\end{array}$ \\
\hline 1 & IMP-1 (Imperial Valley 1940) & 0.348 & 1.27 \\
2 & IMP-2 (Imperial Valley 1940) & 0.214 & 1.81 \\
\hline 3 & PARK-1 (Parkfield 1966) & 0.357 & 1.42 \\
4 & PARK-2 (Parkfield 1966) & 0.272 & 1.95 \\
\hline 5 & IMP-3 (Imperial Valley 1979) & 0.169 & 2.64 \\
6 & IMP-4 (Imperial Valley 1979) & 0.157 & 2.00 \\
\hline 7 & MAM-1(Mammoth Lake 1980) & 0.430 & 1.72 \\
8 & MAM-2 (Mammoth Lake 1980) & 0.271 & 2.05 \\
\hline 9 & NAHAN-1 (Nahanni, 1985) & 0.148 & 5.87 \\
10 & NAHAN-2 (Nahanni, 1985) & 0.139 & 7.15 \\
\hline 11 & SPI-1 (Spitak, 1988) & 0.199 & 2.31 \\
12 & SPI-2 (Spitak, 1988) & 0.175 & 2.68 \\
\hline 13 & LOMA-1 (Loma Prieta 1989) & 0.411 & 0.89 \\
14 & LOMA-2 (Loma Prieta 1989) & 0.473 & 0.72 \\
\hline 15 & LOMA-3 (Loma Prieta 1989) & 0.244 & 1.72 \\
16 & LOMA-4 (Loma Prieta 1989) & 0.240 & 1.77 \\
\hline 17 & LOMA-5 (Loma Prieta 1989) & 0.247 & 1.74 \\
18 & LOMA-6 (Loma Prieta 1989) & 0.215 & 1.62 \\
\hline 19 & NORTH-1 (Northridge 1994) & 0.165 & 3.16 \\
20 & NORTH-2 (Northridge 1994) & 0.217 & 2.08 \\
\hline
\end{tabular}

The inter-story drift results of nonlinear time history analysis for the above structural types 1-4 and types 5-8

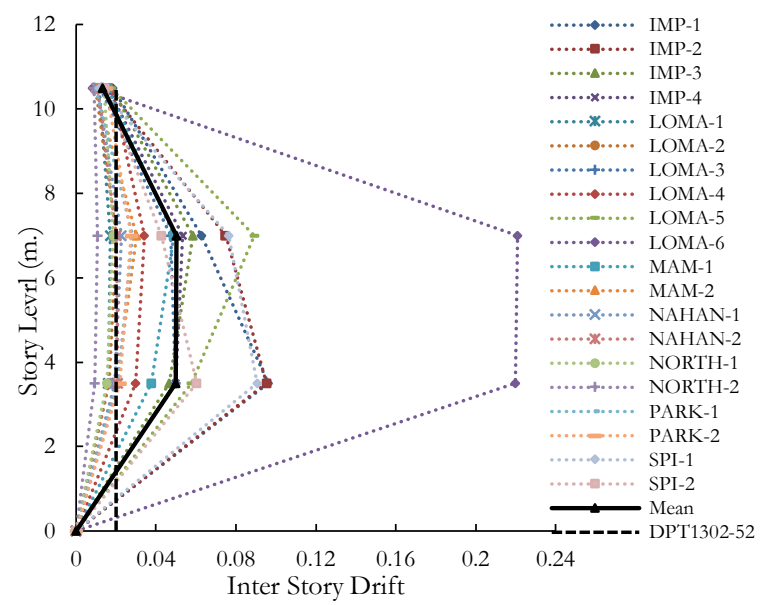

(a) Type 1 (BF-F) are presented in Figs. 12(a)-12(d), and Figs. 13(a)-13(d), respectively. For the existing bare frame Type 1, the mean inter-story drift of the first and the second floor is 0.055 , which is much greater than the allowable limit of 0.02 according to DPT (2009) [31]. The effects of flexible foundation lead to an increase of the mean inter-story drifts for the first and the second floor of frame Type 3 up to 0.06 and 0.07 , respectively. This is due to the lengthening of the effective period of structure as described in the previous section. After retrofitting, the mean inter-story drifts for both frames of the fixed base and the flexible foundation (Type 2 and Type 4) are decreased to 0.011 and 0.012 , respectively, which are within the acceptable limit.

For the case of infilled frame, the peak inter-story drift of the frame Type 5 with the mean value of 0.062 can be observed at the second floor. This is due to the presence of infill panels at both ends of the first floor that enhanced the stiffness of the first floor. The stiffness of the first floor is higher than the second floor; therefore, the peak inter-story drift was shifted to the second floor. The retrofit frame with the additional strengthened infill panel through the full height of the frame could reduce the mean inter-story drifts for the strengthened frame Type 6 to 0.008. Similarly for the case of flexible foundation, the mean inter-story drift of the existing frame Type 7 of 0.065 was observed at the second floor. After retrofitting, the mean inter-story drift of the strengthened frame Type 8 was decreased to an acceptable value of 0.014 . It was found that the effect of the strengthened infill panel significantly improved the inter-story drift. The effects of flexible foundation slightly increased the inter-story drift of the existing and the retrofit frames.

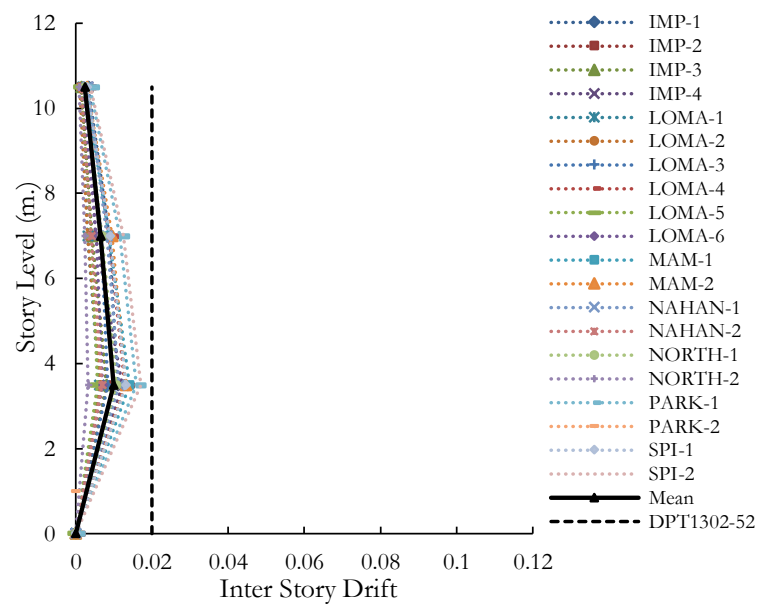

(b) Type 2 (BF-F-ST) 


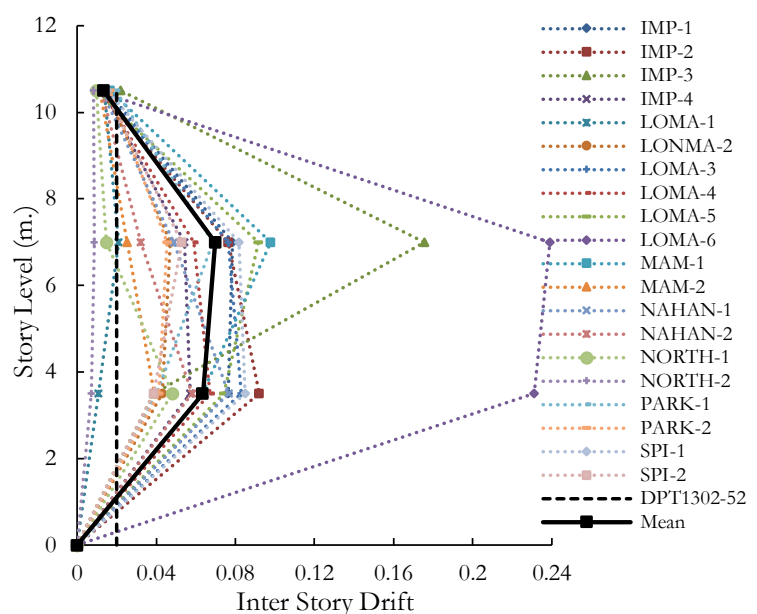

(c) Type 3 (BF-SP)

Fig. 12. Inter-story drift of Bare Frame.

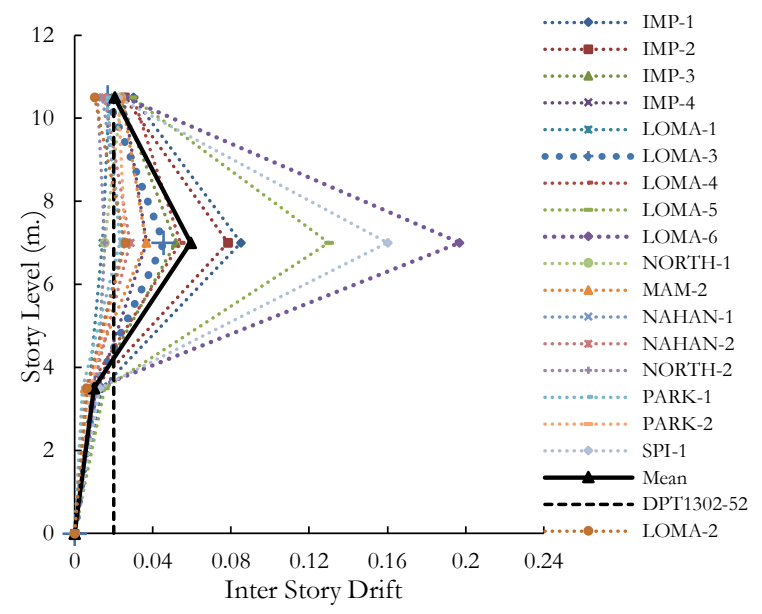

(a) Type 5 (IF-F)

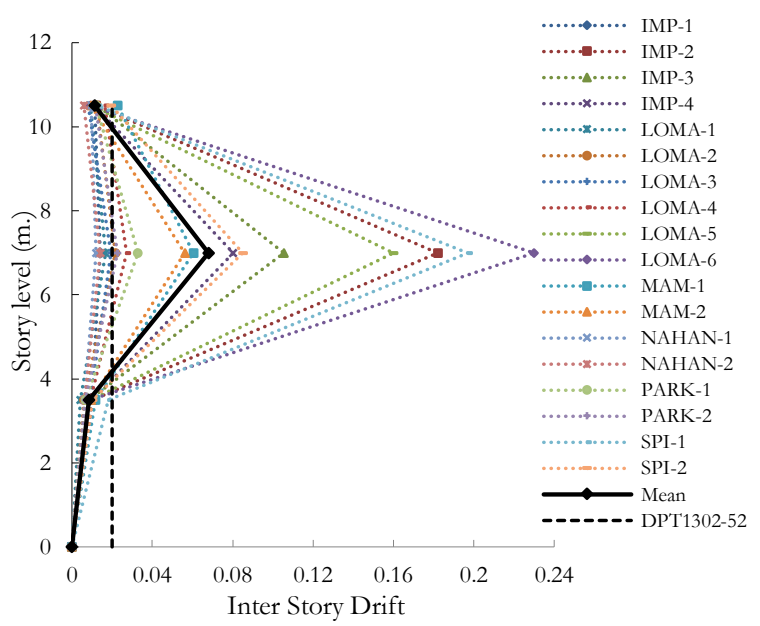

(c) Type 7 (IF-SP)

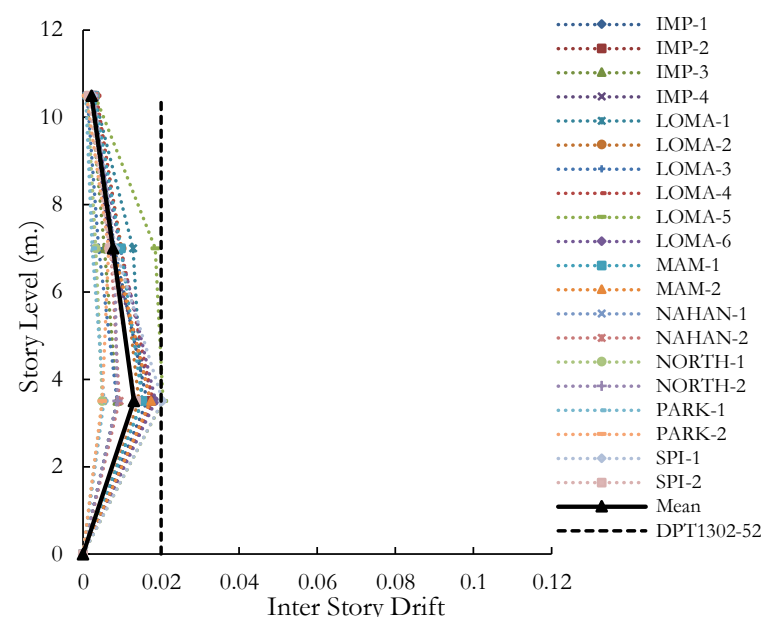

(d) Type 4 (BF-SP-ST)

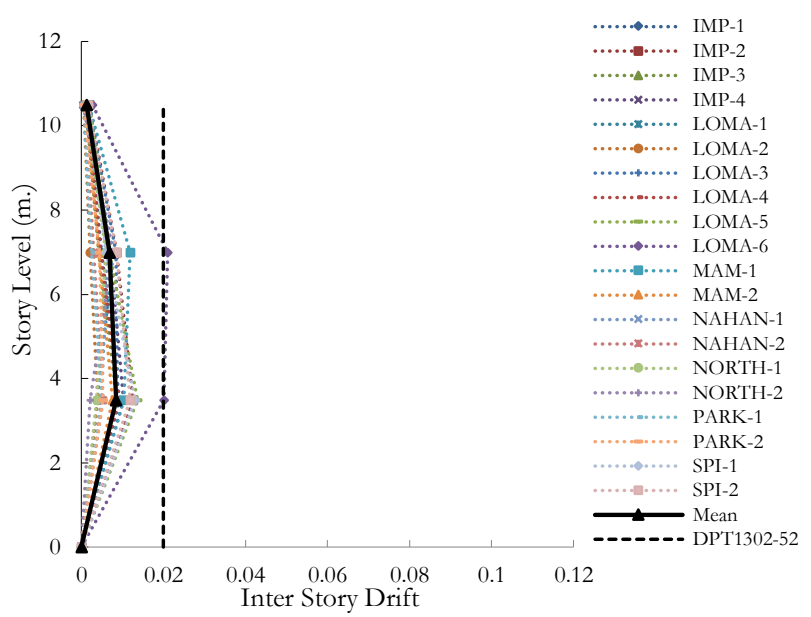

(b) Type 6 (IF-F-ST)

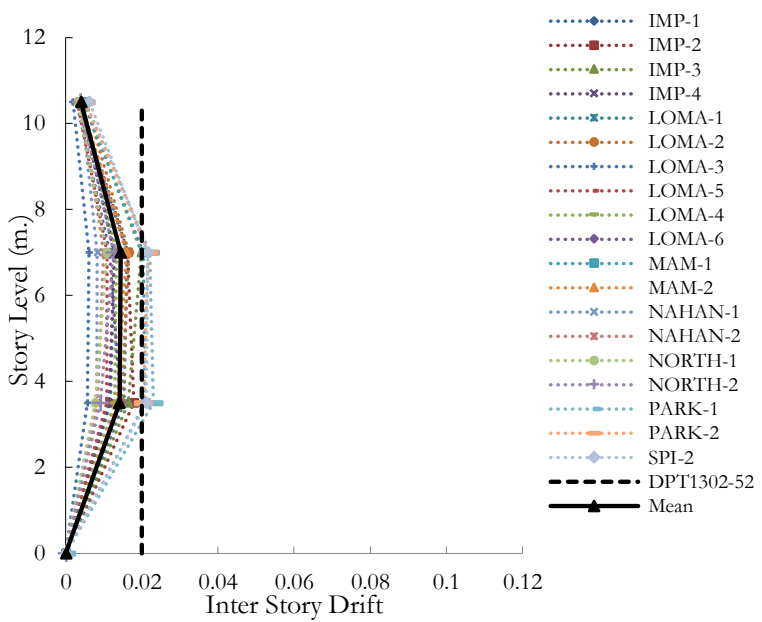

(d) Type 8 (IF-SP-ST)

Fig. 13. Inter-story drift of Infilled Frame. 
To investigate the plastic hinge formation at the beam and column members, the results of Loma-5 ground motion which provided the extreme condition in terms of displacement and damage were selected for this study. The plastic hinge formation including the seismic damage of the bare frames and the infilled frames are presented in Figs. 14(a)-14(d) and Figs. 15(a)-15(d), respectively. The seismic damage of structural members is presented in terms of Damage Index (DI) proposed by Park and Ang (1985) [32]. The damage which DI $\leq 0.6$ is repairable damage, when the damage which $0.6<\mathrm{DI} \leq$ 1.0 is unrepairable damage, and when DI exceed 1.0, it is the collapse condition. For the existing bare frame Type 1 , the plastic formation occurred at the lower end of the ground floor columns and the upper end of the second floor columns with the average DI values of 0.85 and 0.88 , respectively. The beams at the second floor experienced severe damage with the average DI value exceeded 1.0 due to the excessive deformation of the plastic hinges at both ends of beams. The strengthened frame Type 2 revealed that plastic hinges occurred only at the ground floor beams, and the average DI was reduced to 0.38 . The strengthening technique could protect against the plastic hinge formations at the critical regions. The effects of flexible foundation could enhance the plastic hinge formation of the existing bare frame Type 3. The upper end of the second floor columns and the ground floor beams encountered severe damage with the average DI value exceed 1.0. On the contrary, the strengthened frame Type 4 showed a satisfactory improvement, the plastic hinges occurred only at the ground floor beams with the average DI of 0.59 .

For the existing infilled frame Type 5, the stiffness of the second floor was lower than the first floor due to the

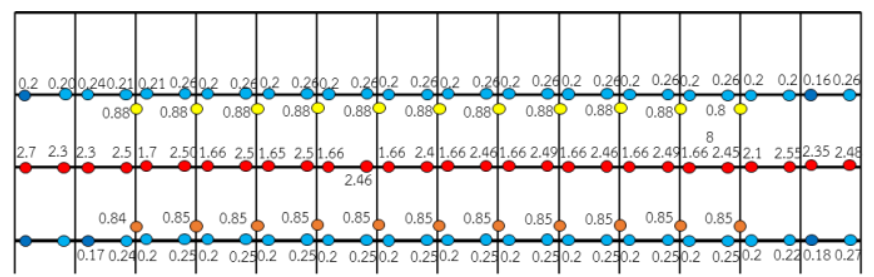

a) Type $1(\mathrm{BF}-\mathrm{F})$

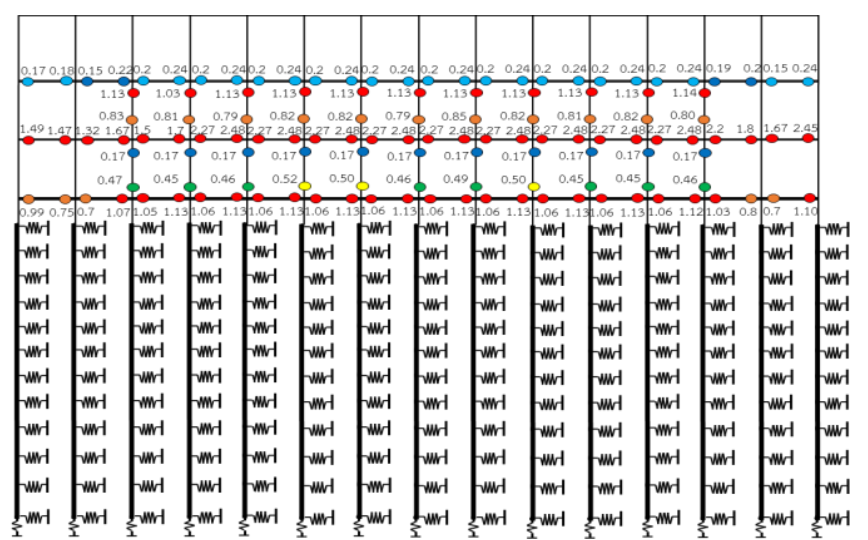

c) Type 3 (BF-SP) presence of the brick infill panel at both ends of the ground floor frame. The critical region was shifted to the second floor columns with the plastic hinges formation at both ends of columns. The partial infill panel at the second floor created the short column behavior in the column height region above the infill panel that unconfined by the partial infill panel. The average DI of the lower and the upper ends of the second floor columns are 0.81 and 0.88 , respectively. The strengthened infill frame Type 6 was significantly improved. The plastic hinges occurred only at the ground floor beams with the average DI of 0.46. The effects of flexible foundation increased the seismic damage of the second floor columns of the existing infilled frame Type 7 ; with the average DI exceed 1.0. In contrast, the strengthened infill frame Type 8 showed a successful improvement, the plastic hinges occurred only at the ground floor beams with the average DI of 0.55.

The results of nonlinear time history analysis revealed that the second floor column of the existing infilled frame was subjected to the maximum shear force of $87 \mathrm{kN}$ at the end of column attaching the infill panel due to the short column effect. The exerted shear force was greater than the calculated shear strength of the existing column of $82 \mathrm{kN}$, which indicated that the column may be inevitably failed by shear. The design shear force of the strengthened column was calculated by using Eq. (5) and Table 3 with the height $\mathrm{h}=2.0 \mathrm{~m}$, one can obtain the design shear force of $133.27 \mathrm{kN}$. Since the design shear force of the strengthened column is about $53 \%$ greater than the exerted shear force, the column was successfully protected against shear failure.

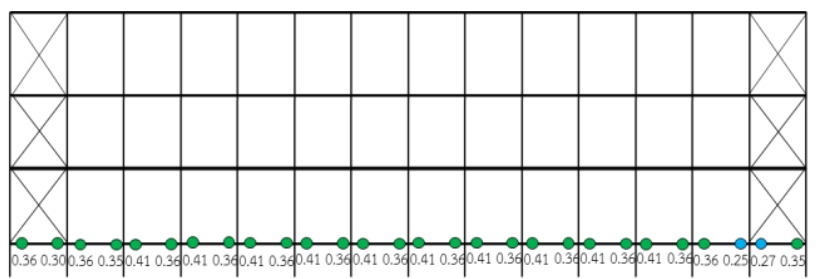

b) Type 2 (BF-F-ST)

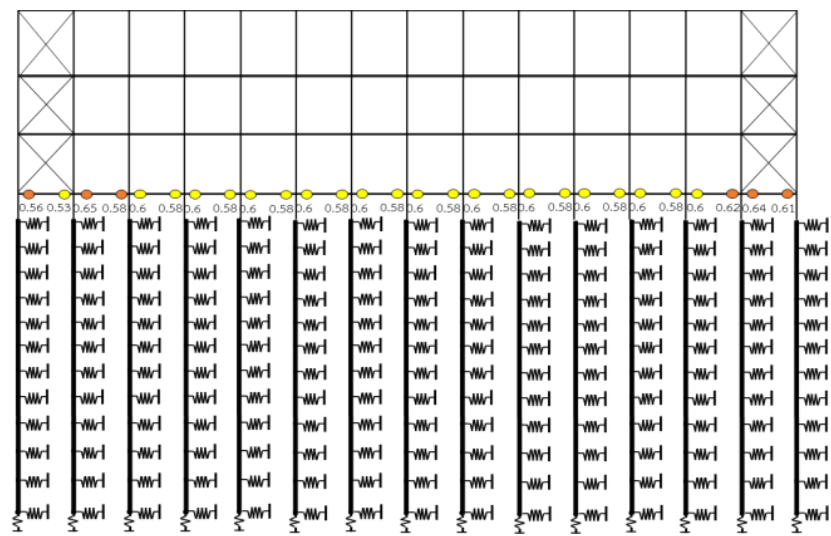

d) Type 4 (BF-SP-ST)

Fig. 14. Seismic damage of Bare Frame. 


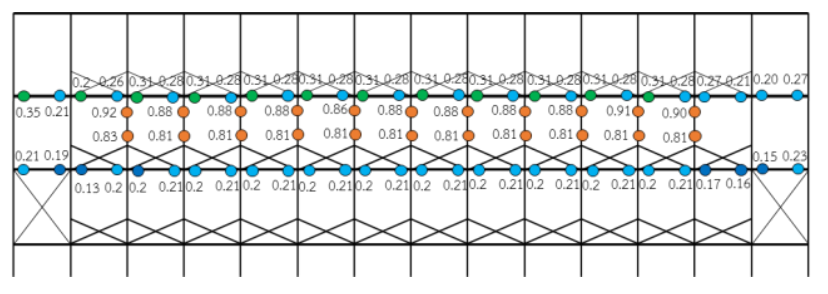

a) Type 5 (IF-F)

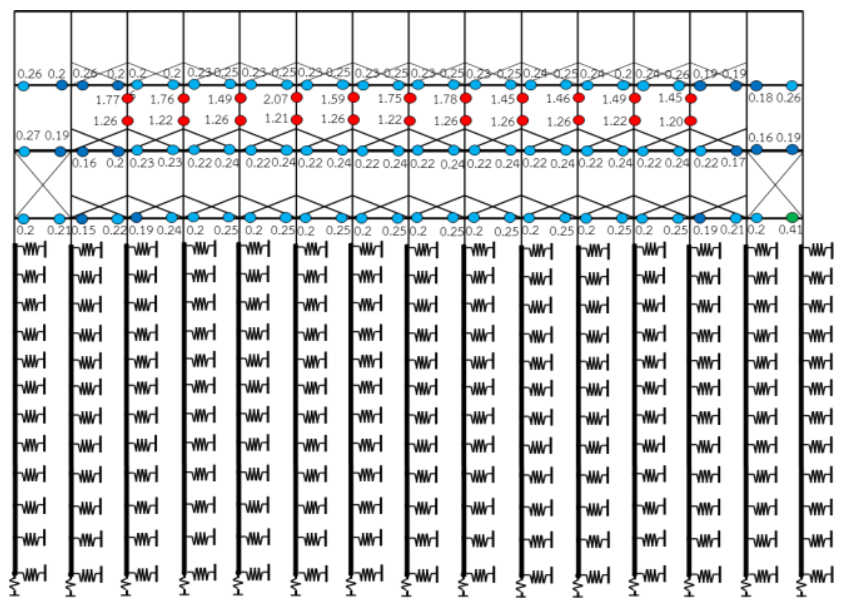

c) Type 7 (IF-SP)

Fig. 15. Seismic damage of Infilled Frame

It should be remarked that the estimation of the construction cost for strengthening of the threestory school building according to the standard school of the National Primary Education Commission No.2/28 is approximately $7.5 \%$ of the construction cost of the new building. Typically, the retrofit cost of the building should not be greater than $20 \%$ of the new building. Therefore, this expense is considered to be economically worth for the retrofit of a school building.

\section{Conclusions}

In this study, the bare frames and the infilled frames strengthened with steel cage and expanded metal techniques were investigated by the nonlinear static analysis and the nonlinear time history analysis. Based on the results of eight types of the existing and the retrofit frames with fixed base and flexible foundation, the conclusions are as follows:

a) For the case of bare frames, the stiffness and strength of the retrofit frame with fixed base are 3.47 and 2.94 times of the existing bare frame. This is due to the contribution of the strengthened brick infill frame at both ends of the frame and the strengthened bare frame at the intermediate columns. For the case of infilled frames, the stiffness and strength of the retrofit frame with fixed base are 2.32 and 1.57 times of the existing infilled frame.

b) The effect of flexible foundation on the strengthened bare frame could reduce the stiffness and strength of

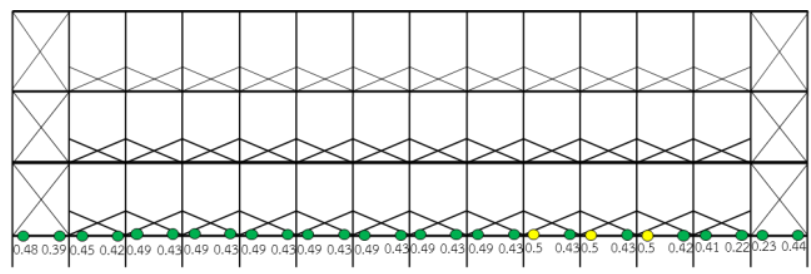

b) Type 6 (IF-F-ST)

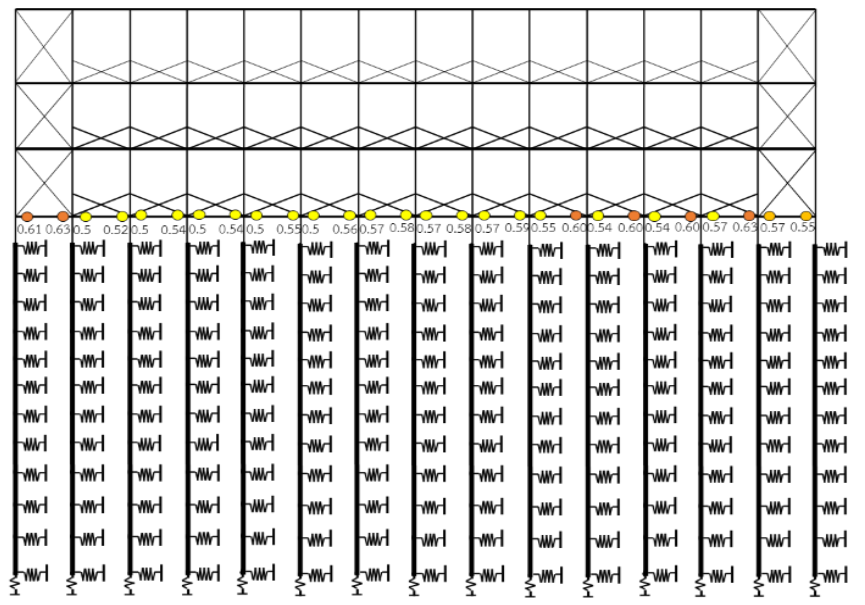

d) Type 8 (IF-SP-ST)

the strengthened bare frame by $45 \%$ and $22 \%$. Similarly, the effect of flexible foundation on the strengthened infill frame could reduce the stiffness and strength of the strengthened infill frame by $27 \%$ and $15 \%$.

c) The mean inter-story drift of the existing bare frame is 0.055 , which is much greater than the allowable limit of 0.02 . The effects of flexible foundation lead to an increase of the mean inter-story drifts up to 0.07 due to the lengthening of the effective period of structure. After retrofitting, the mean inter-story drifts for the bare frames of the fixed base and the flexible foundation are decreased to 0.011 and 0.012, respectively, which are within the acceptable limit.

d) The peak inter-story drift of the infilled frame with the mean value of 0.062 can be observed at the second floor. This is due to the presence of infill panels at both ends of the first floor that enhanced the stiffness of the first floor. The retrofit frame with the additional strengthened infill panel through the full height of the frame could reduce the mean inter-story drifts for the strengthened frame to 0.008 . It was found that the effect of the strengthened infill panel significantly improved the inter-story drift. The effects of flexible foundation slightly increased the inter-story drift of the existing and the retrofit frames.

e) The plastic formation for the existing bare frame occurred at the lower end of the ground floor columns and the upper end of the second floor columns. Severe damage was observed at the second 
floor beams, which the average DI value exceed 1.0. The strengthening technique could protect against the plastic hinge formations at the critical regions. The strengthened frame showed a satisfactory improvement, the plastic hinges occurred only at the ground floor beams with the average DI of 0.59.

f) For the existing infilled frame, the critical region was shifted to the second floor columns with the plastic hinges formation at both ends of columns. The partial infill panel at the second floor created the short column behavior in the column height region above the infill panel that unconfined by the partial infill panel. The strengthened infill frame was significantly improved. The design shear force of the strengthened column is about $53 \%$ greater than the exerted shear force. Therefore, the column was successfully protected against shear failure.

\section{Acknowledgement}

This research is part of the research project "Strengthening of a Prototype School Building for Earthquake Resistant using Expanded Metal and Technology Transferring to a Case Study for School Building in Phan District Chiangrai Community Area," Biodiversity-based Economy Development Office (BEDO), Bangkok.

\section{References}

[1] P. Lukkunaprasit, A. Ruangrassamee, T. Boonyatee, C. Chintanapakdee, K. Jankaew, N. Thanasisathit, and T. Chandrangsu, "Performance of structures in the MW 6.1 Mae Lao earthquake in Thailand on May 5, 2014 and implications for future construction," Journal of Earthquake Engineering, vol. 20, pp. 219-242, 2015.

[2] C. V. R. Murty, M. Greene, S. K. Jain, N. P. Prasad, and V. V. Mehta, "Earthquake rebuilding in Gujarat, India," A Recovery Reconnaissance Report, Earthquake Engineering Research Institute, Oakland, CA, 2005.

[3] S. T. Wasti and G. Ozcebe, "Advances in earthquake engineering for urban risk reduction," in Nato Science Series: IV: Earth and Environmental Sciences.Springer: Netherlands, 2006. vol. 66, no. 6.

[4] P. Nagaprasad, D. R. Sahoo, and D. C. Rai, "Seismic strengthening of RC columns using external steel cage," Earthquake Engineering and Structural Dynamics, vol. 38, pp. 1563-1586, 2009.

[5] H. M. Salman and M. H. Al-Sherrawi, "Interaction diagram for a reinforced concrete column strengthened with steel jacket," International Journal of Civil Engineering and Technology (IJCIET), vol. 9(6), pp. 1369-1377, 2018.

[6] J. G. Roca, Pinilla J. R., J. M. Adam, and P. A. Calderon, "An experimental study on steel- caged $\mathrm{RC}$ columns subjected to axial force and bending moment," Engineering Structures, vol. 33, pp. $580-$ 590, 2011.

[7] C. Campione, "Load carrying capacity of RC compressed columns strengthened with steel angles and strips," Engineering Structures, vol. 40, pp. 457465, 2012.

[8] C. Campione, L. Cavaleri, and M. Papia, "Flexural response of external R.C. beam-column joints externally strengthened with steel cages," Engineering Structures, vol. 104, pp. 51-64, 2015.

[9] E. Esmaeeli, F. Danesh, K. F. Tee, and S. A. Eshghi, "Combination of GFRP sheets and steel cage for seismic strengthening of shear-deficient corner RC beam-column joints," Composite Structures, vol. 159, pp. 206-219, 2017.

[10] Y. Lu, I. Hajirasouliha, and A. M. Marshall, "Performance-based seismic design of flexible-base multi-storey buildings considering soil-structure interaction," Engineering Structures, vol. 108, pp. 90103, 2016.

[11] C. Medina, G. M. Alamo, L. A. Padron, J. J. Aznarez, and O. Maeso, "Application of regression models for the estimation of the flexible-base period of pile-supported structures in continuously inhomogeneous soils," Engineering Structures, vol. 190, pp. 76-89, 2019.

[12] M. Choiniere, P. Paultre, and P. Leger, "Influence of soil-structure interaction on seismic demands in shear wall building gravity load frames," Engineering Structures, vol. 198, 2019.

[13] O. M. O. Ramadan, S. S. F. Mehanny, and A. A. M. Kotb, "Assessment of seismic vulnerability of continuous bridges considering soil-interaction and wave passage effects," Engineering Structures, vol. 206, 2020.

[14] G. Tumialan, K. Nakano, H. Fukuyama, and A. Nanni, "Japanese and North American guidelines for strengthening concrete structures with FRP: A comparative review of shear provisions," in NonMetallic Reinforcement for Concrete Structures-FRPRCS-5, Cambridge, 2001.

[15] A. Leeanansaksiri, P. Panyakapo, and A. Ruangrassamee, "Seismic capacity of masonry infilled RC frame strengthening with expanded metal ferrocement," Engineering Structures, vol. 159, pp. 110-127, 2018.

[16] S. Longthong, P. Panyakapo, and A. Ruangrassamee, "Seismic strengthening of RC frame and brick infill panel using ferrocement and expanded metal," Engineering Journal, vol. 24, no. 3, pp. 45-59, 2020.

[17] R. Amornpunyapat, P. Panyakapo and M. Panyakapo, "Development of lightweight concrete interlocking block panel with water treatment sludge and expanded metal ferrocement," Engineering Journal, vol. 25, no.1, pp. 81-97, 2021.

[18] A. Saneinejad, B. Hobbs, "Inelastic design of infilled frames," Journal of Structural Engineering. ASCE, vol. 121, no. 4, pp. 634-50, 1995. 
[19] P. Panyakapo, "Research and development of strengthening of a prototype school building for earthquake resistant using expanded metal and technology transferring to a case study for school building in Phan District Chiangrai Community Area," Biodiversity-based Economy Development Office (BEDO), Bangkok, 2017.

[20] Expanded Metal Standard by Japanese Industrial Standard, JIS Standard No. JIS G3351, Japanese Standards Association, 1987.

[21] A. J. Carr, "RUAUMOKO-inelastic dynamic analysis program," Department of Civil Engineering, University of Canterbury, Christchurch, New Zealand, 2006.

[22] S. Otani, "SAKE: A computer program for inelastic response of RC frames to earthquakes," Report UILU-Eng-74-2029, Civil Engineering Studies, University of Illinois at Urbana-Champaign, 1974.

[23] M. Saiidi and M. A. Sozen, "Simple and complex models for nonlinear seismic response of reinforced concrete structures," Report UILU-ENG-79-2031, Department of Civil Engineering, University of Illinois, 1979.

[24] P. Panyakapo, "Cyclic pushover analysis procedure to estimate seismic demands for buildings," Engineering Structures, vol. 66, pp. 10-23, 2014.

[25] Ensoft, LPILE (2019). A Program for the Analysis of Piles and Drilled Shafts Under Lateral Loads. Ensoft, Inc., 2019.
[26] L. C. Reese, "Laterally loaded piles: Program documentation," Journal of Geotech. Engg. Div., ASCE, vol. 103, no. GT4, pp. 287-305, 1977.

[27] L. C. Reese and W. F. Van Impe. "Single piles and pile groups under lateral loading," Netherlands, A. A. Balkema, 2001.

[28] Ensoft, Inc., APILE (2019). A Program for Analyzing the Axial Capacity and Short-Term Settlement of Driven Piles under Axial Loading. Ensoft, Inc., 2019.

[29] American Petroleum Institute, "API recommended practice for planning, designing and constructing fixed offshore platforms," Report RP-2A, 1993.

[30] Seismic Rehabilitation of Existing Buildings, ASCE/SEI 41-06, American Society of Civil Engineers, 2006.

[31] Seismic Design Standard of Buildings, DPT 1302-52, Department of Public Works and Town \& Country Planning, Ministry of Interior, 2009.

[32] Y. J. Park and A. H. Ang, "Mechanistic seismic damage model for reinforced concrete," Journal of Structural Engineering, ASCE, vol. 111, no. 4, pp. 722-739, 1985. 


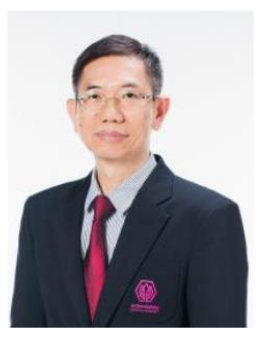

buildings.
Phaiboon Panyakapo received the B.Eng. degree in civil engineering from Kasertsart University, Bangkok, Thailand in 1982 and the M.Eng. and D.Eng. degrees in structural engineering from Asian Institute of Technology, Pathumthani, Thailand, in 1984 and 1999.

From 1997-2000, he was a lecturer at Department of Civil Engineering, School of Engineering, Sripatum University. Since 2004, he has been an Associate Professor at the Civil Engineering Department, Sripatum University, Bangkok, Thailand. He is the author of three books, more than 20 articles, and 1 invention (in patent process). His research interests include building design, seismic design, precasted concrete design, performance based design and seismic retrofit of 